\title{
呼吸の周期性を考慮した異常肺音の自動検出
}

\section{Detection of Abnormal Lung Sounds Through Investigation of Breathing Cycle}

\author{
喜 安千 弥, \\ 正会員 宮原末 治†, \\ 柳 原幸 輔†, \\ 正田備也光, \\ 岡 三 喜 男胡
}

Senya Kiyasu $^{\dagger}$, Kohsuke Yanagihara ${ }^{\dagger}$, Tomonari Masada ${ }^{\dagger}$, Sueharu Miyahara $^{\dagger}$ and Mikio Oka ${ }^{\dagger \dagger}$

\begin{abstract}
The purpose of our research is to develop a method for recognizing abnormal lung sounds without the need of a medical specialist. Listening to the sounds of the human body is one of the most important methods of checking someone's health. However, identification of abnormal lung sounds is difficult for an untrained person. We differentiated true abnormal sounds from interfering noise by investigating the fact that lung sounds are generated periodically in relation to the breathing cycle.
\end{abstract}

キーワード：電子聴診器，呼吸音，スペクトル，異常検出，雑音，識別

\section{1. まえがき}

聴診は, 簡便で安全・安価なすぐれた診察手段として広く 用いられている1).しかし，経験を積んだ医師でなければ 生体の異常音を聞き分けることは難しいため，従来，一般 の家庭では聴診器はほとんど利用されていなかった. 我々 は, 聴診器を日常的な健康管理にも利用できるようにする ことを目指して, 電子デバイスをセンサとして用いた電子 聴診器 2)3)を利用して肺音を入力し, 周波数スペクトルと その時閒変化に着目して異常肺音を自動的に検出する技術 の開発を進めている ${ }^{4) 5)}$. この技術は, 高齢者の在宅介護 などの場面で日常の健康管理に役立つと同時に，医師が患 者を診察する際に医師に有益な情報を提供する診断支援シ ステムとしても活用できる。

聴診器に混入した杂隹音は肺音の異常と間違う可能性があ るため, 異常肺音を正しく検出するには, 雑音と肺音を精 度良く識別する方法が必要である。ここでは，呼吸の周期 に同期して聴診音を記録し，それを用いて肺音のスペクト ルを時系列に抽出し, さらに, 定常的な雑音の影響を除去 した後, 呼吸に伴って周期的に出現する異常音のスペクト ルを選択的に検出する方式について報告する.

2007 年 9 月 5 月受付, 2007 年 10 月 29 月再受付, 2007 年 10 月 30 月 採録

†長崎大学 工学部 情報システム工学科

(广 852-8521 長㥓市文教町 1-14，TEL 095-819-2582)

†川崎医科大学 呼吸器内科

( ( 7 701-0192 倉敷市松島 577, TEL 086-462-1111)

$\dagger$ Faculty of Engineering, Nagasaki University

(1-14, Bunkyo-machi, Nagasaki 852-8521, Japan)

$\dagger \dagger$ Department of Medicine, Kawasaki Medical School

(577, Matsushima, Kurashiki 701-0192, Japan)

\section{2. 異常肺音とその特徵}

健常者の正常肺音と, 肺線維症患者の捻髪音を含んだ異 常肺音の波形とスペクトログラムを図 1 に示す。呼吸の 1 周期を切り出して表示したものであり, 前半が吸気, 後半 が呼気に相当する。 1 周期全体にわたる平均スペクトルを 図 2 に示す。この異常肺音では, 正常音に捻髪音が重畳し ているため, スペクトルにおいても正常肺音のスペクトル に $1 \mathrm{kHz}$ 前後の比較的高い捻髪音の㓤波数成分が加算され て現れている，肺音は呼吸に伴って発生するため, 異常音 も呼吸の位相に同期して発生する。図 1 の例では，捻髪音 は吸気区間と呼気区間のそれぞれ中央部分で発生している ことがわかる。したがって，このような異常音を精度良く 検出するには，呼吸の位相をふまえた解析が必要である。

\section{3. 異常肺音の検出}

\section{1 呼吸の位相と肺音の入力}

肺音と呼吸の位相を正確に対応づけるには，スパイロメー タで吸気と呼気の流量を測定しながら肺音を入力する方法 があるが，簡便な計測には不向きである．本研究では呼吸 のタイミングを被験者に指示しながら肺音を入力するシス テムを開発した．肺音入力時の表示画面を図 3 に示す.シ ステムは画面上に図のような楕円を表示し，被験者はこの 楕円の膨張・収縮のアニメーションにあわせて吸う・吐くの 動作を行う。アニメーションのタイミングを肺音と同時に 記録しておくことにより，解析時に吸気区間と呼気区間を 区別して肺音の 1 周期を自動的に抽出することができる。 

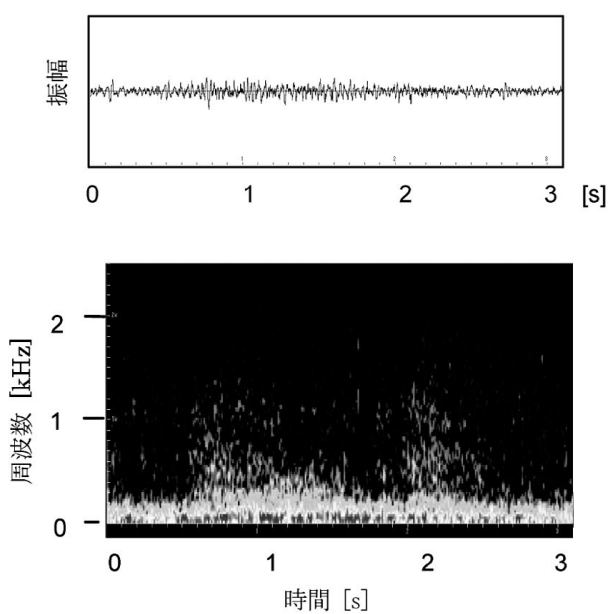

(a) 正常肺音
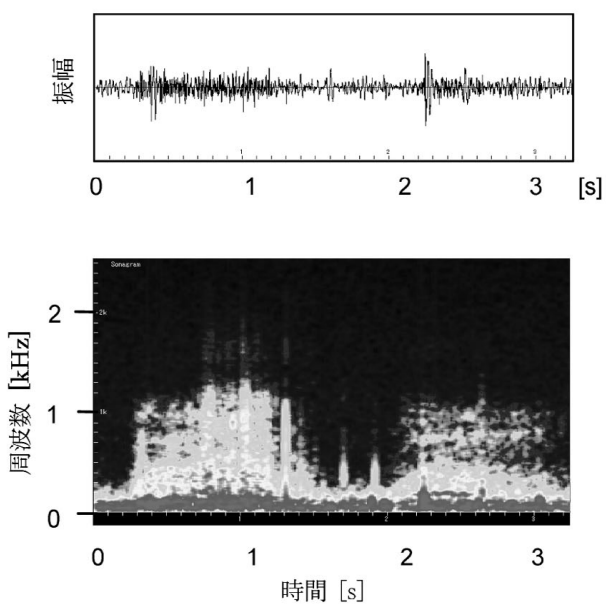

(b) 異常肺音 (捻髪音)

図 1 肺音の波形とスペクトログラム

Waveform and spectrogram of lung sounds.

\section{2 識別区間の設定と平均スペクトルの算出}

入力された肺音データに対して，吸気の開始から呼気の 終了までを 1 周期とし，それを複数の区間に分割して各区 間の平均スペクトルを算出する.このとき 1 周期をいくつ かの分割点で排他的に分割すると, 分割点をまたいで発生 した異常音が，前後のどちらの区間に扝いても安定して検 出できないおそれがある。そこで，どの時刻に異常音が発 生してもいずれかの区間で充分にカバーできるようにする ため，ここでは吸気と呼気からなる 1 周期に対して，図 4 に示すように，それぞれ $1 / 2$ 区間ずつオーバラップした複 数の区間を設定して解析を行った。これらの区間に対して， それぞれ異常音とみなせるか否かの識別を行うため, ここ ではこれらの区間を「識別区間」と呼ぶ．例えば，1 周期 の長さを $T$ とし, 識別区間の幅を $T / 8$ に選ぶと, 半分ず つオーバラップした全部で 15 の識別区間が設定される.

次に，それぞれの識別区間について，平均スペクトルを計 算する。ここでは，図 5 に示すように識別区間の先頭から 順に 512 点からなる短区間データを 256 点ずつオーバラッ プさせながら抽出する. そして, それぞれの短区間データ に対して，ハミング空を用いた FFT 処理を行って周波数 スペクトルを算出し，その平均值を識別区間の平均スペク

$1770 \quad(90)$

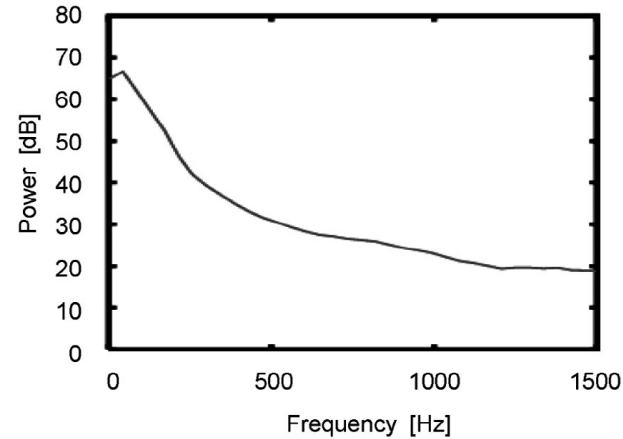

(a) 正常肺音

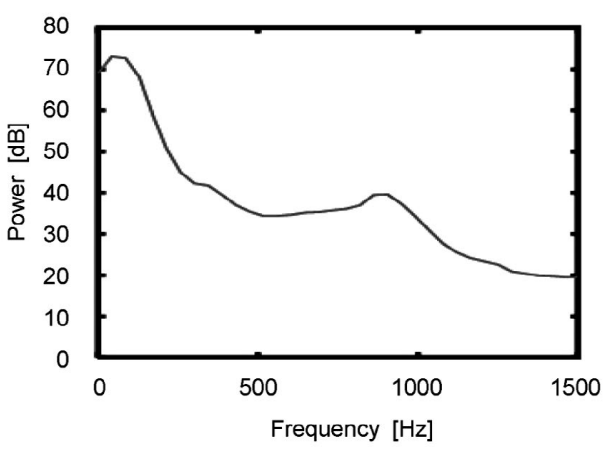

(b) 異常肺音 (捻髪音)

図 2 肺音のスペクトル (1 周期平均) Spectrum of lung sounds (average of one cycle).

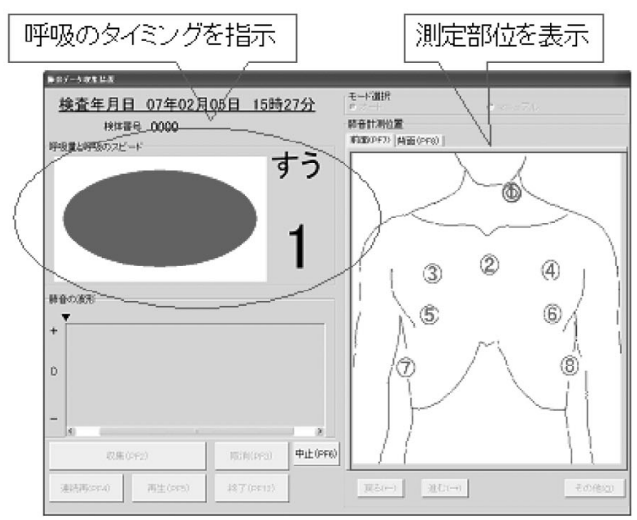

図 3 肺音入力システム画面

Lung sounds acquisition system.

トルとする.サンプリング周波数を $11.025 \mathrm{kHz}$ とした場合 には，512 点のデータの時間幅は約 $46 \mathrm{~ms}$ に相当する。

\section{3 定常的な雑音成分の除去}

それぞれの識別区間のスペクトルに基づいて異常音の有 無を検出しようとすると，異常音に類似した雑音を誤検出 する可能性がある．雑音としては，空調音などの環境から の定常的な雑音と, 聴診器の物理的な接触に起因する突発 的な雑音が考えられるが，ここではまず，定常的な雑音の 影響を低減する処理を考える。

吸気と呼気の境界点では，空気の流れが一度停止するた め，肺音が発生しない時点が存在すると考えられる。した 


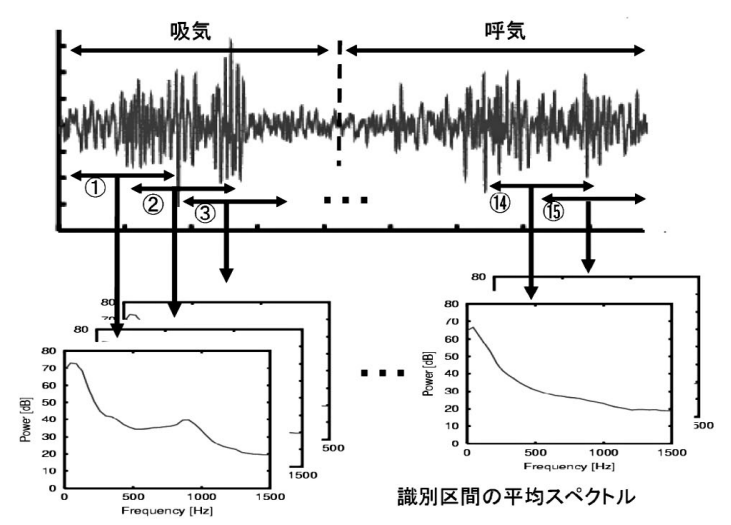

図 4 識別区間の設定 Setting of objective segments for recognition.
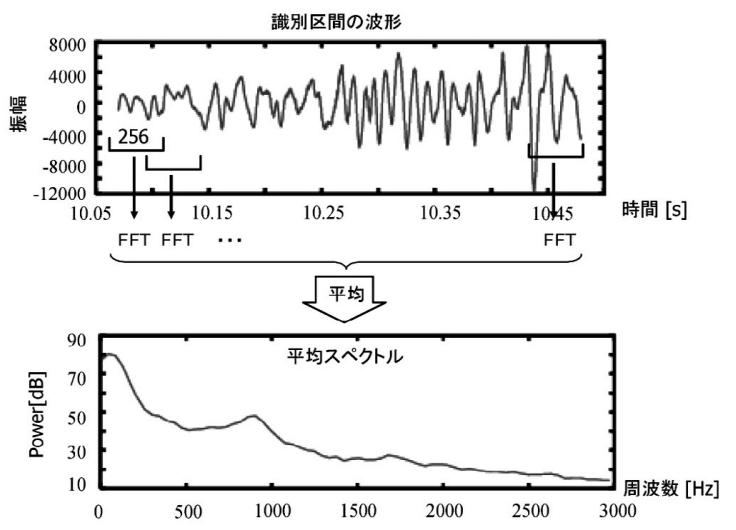

図 5 各識別区問の平均スペクトル算出

Calculation of mean spectrum for each objective segment.

がって，連続的に聴取した肺音において最も検出レベルが 小さい区間が, 肺音以外の雑音を反映していると考える。そ こで，識別区間の平均スペクトルの算出に用いた 512 点の 短区間スペクトルについて，5区間の移動平均をとりなが ら周波数ごとの最小值を検出する。ここでは, このように して得られたスペクトルの最小值を識別区間ごとの定常的 な雑音のスペクトルと考えた. 定常的な雑音のスペクトル を減算することによって, 図 6 のように定常雑音を除いた 肺音のスペクトルが推定される。

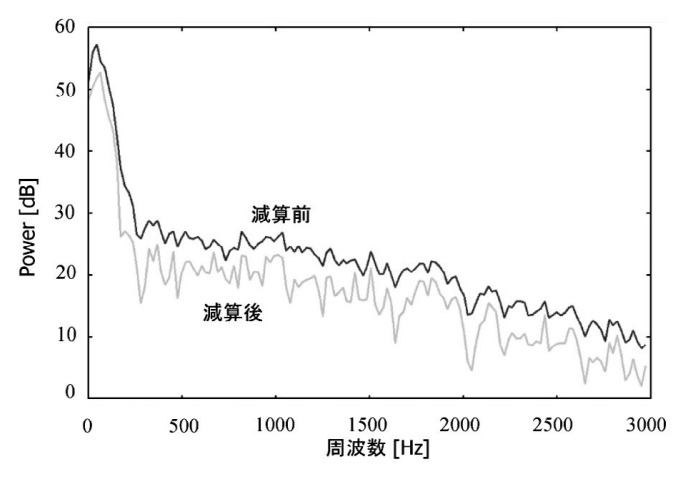

図 6 定常的な雑音成分の減算 Spectral subtraction of stationary noise.

\section{4 識別区間に対する異常音の識別}

各識別区間について計算された肺音のスペクトルをあら かじめ用意した教師データのスペクトルと比較して, 正常 音か異常音かを識別する。ここでは, 正常音と異常音のあ いだでパワーに差が見られない周波数帯域を選択し，その 帯域の平均パワーが等しくなるように，あらかじめスペク トル全体に係数をかけて正規化しておく。これにより，肺 音の検出レベルの違いに影響を受けずにスペクトルの特徴 を比較することができる。ここでは，2000 3000Hz を基 準として正規化を行った。

様々な異常音に対して教師データの数は限られることを 考慮し，ここではノンパラメトリックな事例ベースの識別 手法 ${ }^{6)}$ を利用した．以下の実験では，各波長のスペクトル 值を並べて特徽ベクトルとし， $k$ 近傍法 ${ }^{6)}$ を用いて識別を 行った.

\section{5 呼吸の周期性を利用した異常肺音の検出}

正常音を異常音と誤認識するもうひとつの原因として， 突発的な雑音の影響が考えられる，例えば，聴診器が衣服 や皮虐とこすれて大きな雑音が混入した場合，スペクトル の上では異常肺音と区別がつかない場合がある．このとき， これらの雑音が不規則で突発的であるのに対して，異常肺 音は呼吸周期に同期して複数の周期にわたって繰り返し聴 取されることが多い.このような肺音の周期性を考慮して 異常肺音と突発的な雑音を識別する.

異常音が周期的に発生した肺音と, 突発的な雑音が重畳 した正常肺音を，3 周期にわたって表示した例を図 7 に示 す。この例では, 呼吸に起因する異常音は複数の周期の同 じ識別区間に繰り返し発牛しているのに対し, 杂隹音の発牛. は非周期的である。したがって，図 8 に示すように 3 周期 の識別区閒について多数決をとり, 同じ識別区閒で 2 回以 上異常音が検出された場合には, 異常な肺音が発生してい ると推定する。いずれかの識別区間で異常な肺音が繰り返 し発生した場合に，その肺音全体が異常肺音であると判定 する。

\section{4. 異常肺音の検出実験}

上記のアルゴリズムを実際の肺音デー夕に適用し, 異常 肺音の検出実験を行った。実験には, 健常者 20 名から得ら れた正常肺音と, 各種の疾患をもつ患者 27 名から得られた 異常肺音を用いた。実験に用いた肺音の聴診位置は，図 9 に示した前面 2 力所, 背面 1 力所の合計 3 カ所である. 正常 音のスペクトル 1290 データと異常音のスペクトル 703 デー 夕を，予備実験を通して教師データとして抽出した。これ らの教師データは, 識別区間や聴診位置の違いを考慮せず に選択している。ささにテストデータとして，正常肺音 45 例と異常肺音 45 例のデータを用いた。これらは，3カ所の 聴診位置ごとに正常と異常をそれぞれ 15 例ずつ選択した ものである。

データ収集時には, サンプリング周波数を $44.1 \mathrm{kHz}$ とし 


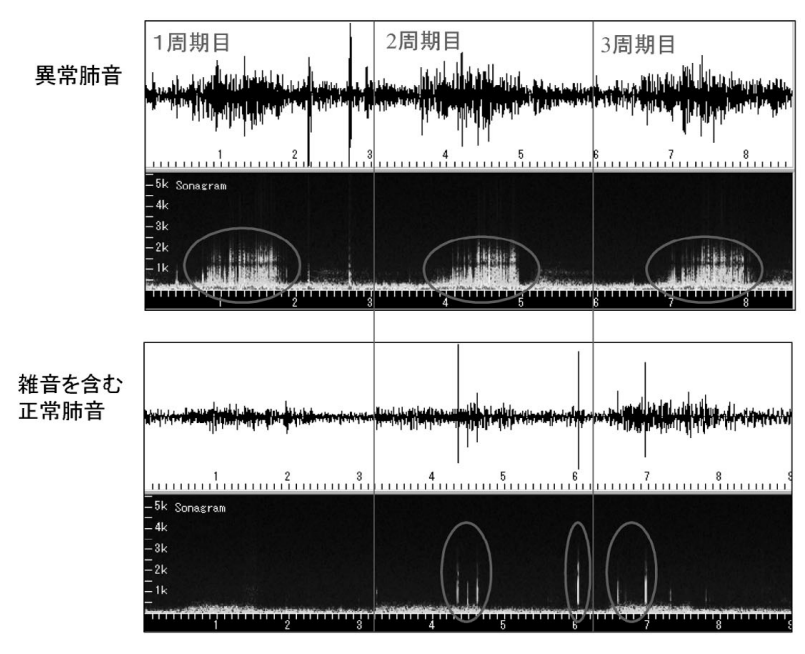

図 7 周期的な異常音と非周期的な雑音 Periodic abnormal lung sounds and non-periodic noise.

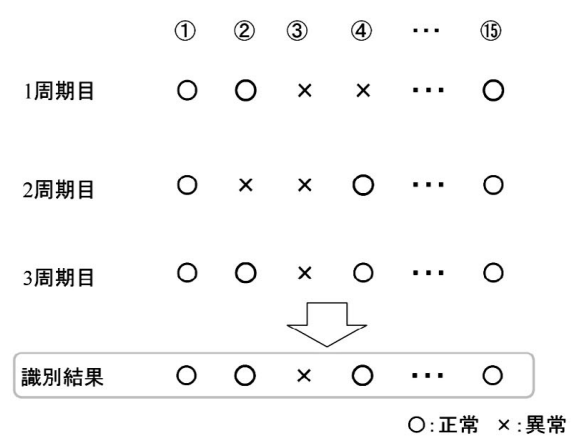

図 8 周期性に基づく雑音の識別

Discrimination of non-periodic noise.

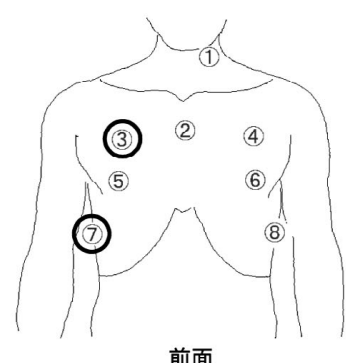

前面

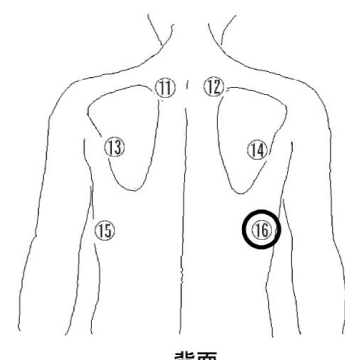

背面
目 9 肺音の聴診位置

Listening points for lung sounds.

て電子聴診器の出力を肺音入力システムで収録し, 解析時 には，このデータを $11.025 \mathrm{kHz}$ にダウンサンプリングして 用いた. 1 周期の識別区間数は 15 区間とし，異常音の認識 には，パラメータ $k$ を 5 として $k$ 近傍法を用いた。 周期性 を利用せずにそれぞれの呼吸周期について異常の有無を検 出した結果を表 1 に示す。これに対して, 周期性に基づい て 3 周期の多数決で異常の有無を決定した結果を表 2 に 示す．周期性を用いない場合には，正答率が平均 $84.8 \%$ で あったのに対して，周期性を用いた場合には $93.3 \%$ まで 昇した。この結果より，周期性を利用して異常肺音を検出
表 1 実験結果 (周期性利用なし)

Results of recognition (without discrimination of nonperiodic noise).

\begin{tabular}{c|c|c|c|c}
\hline \hline 聴診位置 & 3 & 7 & 16 & 合計 (正答率, 正答数) \\
\cline { 1 - 2 } 正常 & $30 / 45$ & $35 / 45$ & $35 / 45$ & $84.8 \%$ \\
\cline { 1 - 3 } 異常 & $45 / 45$ & $44 / 45$ & $40 / 45$ & $(229 / 270)$ \\
\hline
\end{tabular}

表 2 実験結果 (周期性を利用)

Results of recognition (with discrimination of nonperiodic noise).

\begin{tabular}{c|c|c|c|c}
\hline \hline 聴診位置 & 3 & 7 & 16 & 合計 (正答率, 正答数) \\
\hline 正常 & $14 / 15$ & $15 / 15$ & $14 / 15$ & $93.3 \%$ \\
\cline { 1 - 2 } 異常 & $15 / 15$ & $13 / 15$ & $13 / 15$ & $(84 / 90)$ \\
\hline
\end{tabular}

する方法が有効であることがわかる.

今回の実験では，個々の識別区閒に対する正常音/異常音 の識別に用いた教師データは，テストデータとは独立に全 データから抽出したものである。したがって，テストデー タとして用いたデータの中にも教師データとして使用した 部分が含まれている可能性がある。このため, さらに適切 な評価を行うためには， leave one out 法を用い，テスト データとして使用する個々の識別区間を教師データから除 外して処理を行う必要がある。しかしながら，呼吸の周期 性に基づいて突発的な雑音を除外する第 2 段階の処理は, 教師データを必要としないルールベースの判定処理である. したがって，前記の事情により個々の識別区間の正答率が 高めに評価されているとしても，表 1 と表 2 の結果より周 期性に基づく処理の有効性が確認できると考えられる.

定常的な雑音のスペクトルを推定して減算する手法の効 果を確認するために，雑音成分を減算せずに処理を行った 場合と比較したところ，今回用いたデー夕に対しては，認 識率の向上は $1 \%$ 程度であった。本実験に用いたデー夕は， 教師データとテストデータのどちらも同じ実験環境で得ら れたものであるため, 定常的な雑音にはほとんど差がなく， 雑音低減の効果が表れにくいと考えられる，異なる環境で 雑音が重冨したデー夕を対象とした場合に，効果が示され るかどうかを今後検討してゆく必要がある.

\section{5.むすび}

肺の聴診における異常音の自動検出を目的として, 被験 者に呼吸のタイミングを指示しながら肺音を収録するシス テムを開発した。また，定常的な雑音の影響を除去した後， 呼吸に同期して周期的に出現する異常なスペクトルを検出 することによって，雑音の影響を回避して異常肺音を検出 した．合計 90 例のデー夕について実験を行った結果，約 93\%の精度で正常肺音と異常肺音を識別できた.

今回の実験に用いたデー夕は，実際に健常者および患者 から電子聴診器を用いて得られたデータであるが，今回の 実験では，我々が聞いて明らかに異常音と確認できるデー 夕を選択して実験に利用している。医師でなければ正常と 
異常の聞き分けが困難なデー夕も含め, 多様な対象に対し て効果を確認し，実用化を目指すことが今後の課題である.

\section{〔文献〕}

1）石原恒夫監修, 川城丈夫, 阿部直, 菊池功次, 米丸亮: “CD による聴 診トレーニング 呼吸音編”, 南江堂 (1993)

2）スリーエムヘルスケア (株): Electronic Stethoscope Model 4100, http://www.mmm.co.jp/hc/ littmann/es-4000.html

3) Hanbyul Meditech Co., Ltd: Electronic Stethoscope, http://hbmeditech.en.ec21.com

4) 宮原末治, 田中研勢, 船山稔, 喜安千弥, 早田宏, 岡三喜男, 河野茂: “電 子聴診器による肺音の解析”, 薬理と臨床, 15, 5, pp.511-518 (2005)

5）喜安千弥, 北里圭子, 宮原末治, 早田宏, 河野茂: “肺の聴診における異 常咅の自動検出”, 薬理と臨床, 16, 5, pp.547-555 (2006)

6）石井健一郎, 上田修功, 前田英作, 村瀬洋: “わかりやすいパターン認識”, オーム社 (1998)

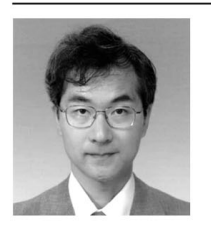

喜安 草弥 1986 年, 束京大学工学部計数工学科 卒業. 同年 (株) 日立製作所生産技術研究所勤務. 1991 年, 東京大学工学部計数工学科助手. 2003 年, 長崎大学 工学部助教授. 現在, 准教授. パターン認識, リモート センシングなどの研究に従事. 博士 (工学).

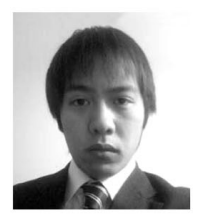

柳原幸幸輔 2007 年, 長崎大学工学部情報システム 工学科卒業. 同年 NTT データネッツ (株) 入社. CAFIS システムの開発に従事.

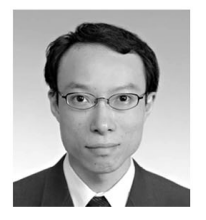

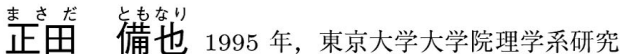
科修士課程修了. 2004 年, 同大学院情報理工学系研究科 博士課程修了. 現在長崎大学工学部情報システム工学科 助教. データ・マイニング, 情報検索の研究に従事. 博 士 (情報理工学) .

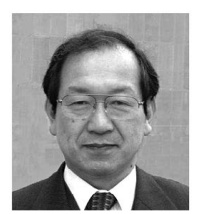

窝原热治 1971 年, 熊本大学大学院工学研究科 修士課程修了. 同年, 日本電信電話公社 (現 NTT) 入社. 1997 年, 長崎大学工学部教授. 現在に至る. 音声情報処 理, パターン認識, 画像処理, 情報検索の研究・開発に 従事. 博士 (工学). 正会員.

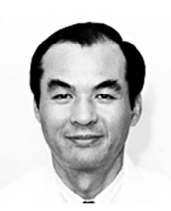

势㔖至喜 1979 年, 長崎大学医学部卒業。長崎 大学医学部助手, 講師, 助教授を経て, 2004 年, 川崎医 科大学内科学 (呼吸器) 教授. 呼吸器疾患一般, 胸部腫 瘍 (とくに肺がん) と癌化学療法, 胸部画像診断, 呼吸 器感染症の診断と治療, アレルギー疾患, 呼吸器内視鏡 などを専門とした診療・研究・教育に従事. 医学博士. 